\title{
ナフタレンの $\pi$-電子系におよぼすメルカプト基の効果
}

\author{
(1975 年 6 月 11 日 受理)
}

\author{
吉野 純子*・河合 久夫**星 敏 彦*
}

1-および 2-ナフタレンチオールの偏光吸収スペクトルの測定および PPP 計算から各遷移モーメント の方向などを決定し，メルカプト基の $\pi$-電子系への効果について考察した。PPP 計算に必要なメルカ プト基の empirical パラメーターの值はつぎのように評価した。すなわち硫黄原子の第 2 イオン化電圧 は $I_{\mathrm{P}}\left(\mathrm{S}^{+}\right)=I_{\mathrm{P}}(\mathrm{S})+(\mathrm{SS} \mid \mathrm{SS})=22.30 \mathrm{eV}$ で近似した。ここで, $I_{\mathrm{P}}(\mathrm{S})$ は硫黄原子の第 1 イオン化電圧で ある。炭素-硫黄間の共鳴積分 $\beta_{\mathrm{CS}}$ は偏光吸収スペクトルの結果を参考にして推定した（最適の $\beta_{\mathrm{CS}}=$ $-2.8 \mathrm{eV})$ 。これらの empirical パラメーターを用いた 1- 抽よび 2-ナフタレンチオールについての計算 結果は遷移モーメントの方も含めて実測値と非常によく一致している。メルカプト基の $\pi$-電子系へ の共鳴効果の大きさを他の置換基（アミノ基など）と比較した。その結果共鳴効果の大きさはつぎのよ らな順序であった。

$$
-\mathrm{OH}<-\mathrm{SH}<-\mathrm{NH}_{2}<-\mathrm{O}^{-}
$$

\section{1 藉言}

窒素や酸素を含む芳香族化合物の電子状態に関する研究はこれ まで理論的执よび実験的な立場から非常に多くの人々によりなさ れてきた。またこれらのように $\pi$-電子系をるつ化合物の電子状 態の研究にはPPP 法による計算が重要な役割を果たしてきた。 PPP 法が提案されて以来 20 年以上経った現在でもこの方法の有 用性は少しも失われていない。近年硫黄を含む芳香族化合物は有 機合成化学的あるいは生物化学的に非常に重要視されているにも かかわらず，この種の化合物の電子状態に関する研究の報告はそ ら多くない。

本研究ではまずMO 計算に必要なメルカプト基の empirical パ ラメーターを評価する。つぎに 1- および 2-ナフタレンチオール のように分子内にメルカプト基をもつ化合物をモデル物質に選 び，延伸高分子膜法による偏光吸収スペクトルの測定結果をもと にして，ここで評価した empirical パラメーターの妥当性につい て考察する。またメルカプト基の $\pi$-電子系への㯰換基劣果をほ かの $2 ， 3$ の官能基の場合と比較し考察する。

\section{2 実験}

2-ナフタレンチオールは市肘品をエタノールと水の混合溶媒か ら2 回再結晶したすのを, 1-ナフタレンチオールは市肘品をその まま用いた。偏光吸収スペクトルの測定はすでに報告された方法 により行なった 1) 3)。

* 青山学院大学理工学部, 157 東京都世田谷区千歳台

** 現在 エイボンプロダクッ株式会社, 130 東京都畦田区緑

1) T. Hoshi, Y. Tanizaki, Z. Phys. Chem. NF., 71, 230 (1970).

2) H. Inoue, T. Hoshi, T. Masamoto, J. Shiraishi, Y. Tanizaki, Ber. Bunsenges. Phys. Chem., 75, 441(1971).

3) T. Hoshi, J. Yoshino, H. Toma, K. Ota, Chem. Lett., 1972, 819.

\section{3 計算}

MO 計算は modified PPP 法を採用した。したがってここで は標準的な PPP 法と異なる点と用いたパラメーターの值を簡単 に述べる。炭素原子の原子価状態でのイオン化電圧 $\left(I_{P}(C)\right)$ 扰よ び電子親和力 $\left(E_{\mathrm{A}}(\mathrm{C})\right)$ はそれぞれ $11.22 \mathrm{eV}$ および $0.62 \mathrm{eV}$ とし た。硫黄原子の第 2 イオン化電圧 $\left(I_{\mathrm{P}}\left(\mathrm{S}^{+}\right)\right)$は適当な実験值が見 あたらなかったのでつぎのように近似した。

$$
I_{\mathrm{P}}\left(\mathrm{S}^{+}\right)=I_{\mathrm{P}}(\mathrm{S})+(\mathrm{SS} \mid \mathrm{SS})=22.3 \mathrm{eV}
$$

ここで, (SS $\mid \mathrm{SS})$ は一中心反発積分で, $(\mathrm{SS} \mid \mathrm{SS})=I_{\mathrm{P}}(\mathrm{S})-E_{\mathrm{A}}(\mathrm{S})$ により評価した。また硫黄原子の第 1 イオン化電圧 $\left(I_{\mathrm{P}}(S)\right)$ およ び電子親和力 $\left(E_{\mathrm{A}}(S)\right)$ はそれぞれ $12.50 \mathrm{eV}$ および $2.70 \mathrm{eV}$ とし だ)。二中心反発積分は西本・又賀の式により評価しだ)。炭素炭素間の共鳴積分 $\beta_{\mathrm{CC}}$ は西本・Forsterの式により SCF 計算のた びごとに新たに計算した。 $\beta_{\mathrm{CS}}$ の評価については後で述べる。配 置間相互作用は被占軌道の上から 5 個と空軌道の下から 5 個との 間のすべての一電子励起配直について考虑した。各分子の座標は 炭素-炭素結合距離を $1.395 \AA$, 炭素-硫黄原子間の絬 合距離を $1.700 \AA$ とし, 結合角度を $120^{\circ}$ として求めた。

\section{4 結果および考察}

\section{1 硫黄原子の empirical ハララメーターの評価}

さきに述べたように PPP 計算を行ならにさいしては, 各原子 の原子洒状態のイオン化電圧, 電子親和力および各原子間の共鳴 積分などの値を半経験的に求めなければならない。炭素原子, 窒 素原子, 酸素原子などについてのこれらの值はこれまで十分に吟

4) H. A. Skinner, O. Pritchard, Trans. Faraday Soc., 49, 1254(1953).

5) N. Mataga, K. Nishimoto, Z. Phys. Chem. NF., 13, 140 (1957). 
味されてきている。しかしながら硫黄原子についての適切なパラ メーターの評価はいまのところ行なわれていない。本研究では硫 黄原子についてのこれらのパラメーターのらち, イオン化電圧の 値は原子スペクトルのデータを基にして(1)式により評価し， ま た電子親和力の值は原子スペクトルから直接推定した。

一般に共鳴積分の評価は重なり積分の大小などから推定する方 法がよく用いられている。たとえば Mulliken 近似では共鳴積分 を重なり積分に比例させ， $\beta_{\mathrm{rs}}=l S_{\mathrm{rs}}$, 比例定数 $l$ を半経験的に求 めている。しかしながら硫黄原子についての適当な $l$ の值はいま のところ見つからないので, 本研究では 2-ナフタレンチオール の偏光吸収スペクトルの結果からßの值を直接推定することにし た。

図 1 に延伸高分子 (ポリビニルアルコール) 膜中に打ける 2-ナ フタレンチオールの偏光吸収スペクトルを示す。この図で $R_{\mathrm{s}}$ は 膜の延伸率， $D_{/ /}$および $D_{\perp}$ は膜の延伸方向に対して入射偏光の 電気ベクトルがそれぞれ平行および直角な場合の吸光度, $R_{\mathrm{d}}$ は 吸光度比 $\left(D_{/ /} / D_{\perp}\right), \theta$ は配向角 (分子の配向軸と遷移モーメント のなす角度）である。この化合物は近紫外部に四つの吸収帯を $29.8 ， 33.9 ， 40.7$ および $45.8 \mathrm{kK}$ にもっている。これらの吸収 帯の配向角は低波数側から $48^{\circ}, 47^{\circ}, 36^{\circ}$ および $41^{\circ}$ となってい る。たとえば $29.8 \mathrm{kK}$ 帯と $33.9 \mathrm{kK}$ 帯の遷移モーメントのなす角 度は両吸収帯の配向角の和 $\left(\theta_{\mathrm{I}}+\theta_{\mathrm{II}}=48^{\circ}+47^{\circ}=95^{\circ}\right)$ あるいは差 $\left(\theta_{\mathrm{I}}-\theta_{\mathrm{II}}=48^{\circ}-47^{\circ}=1^{\circ}\right)$ で表わされ，両吸収帯はたがいにほほ直 角あるいは平行に分極していることになる。このように本実験だ けからは両吸収帯の相対的分極方向を一義的に決定することは困 難であるが，つぎの理由によりこの場合の二つの吸収帯はほぼ同 方向に分極しているすのと思われる。すなわちこの 29.8 および $33.9 \mathrm{kK}$ 帯は後に述べるようにそれぞれナフタレンの ${ }^{1} L_{\mathrm{b}}$ および ${ }^{1} L_{\mathrm{a}}$ に対応している。西本ら ${ }^{6}$ および谷崎ら”はナフタレン骨格の

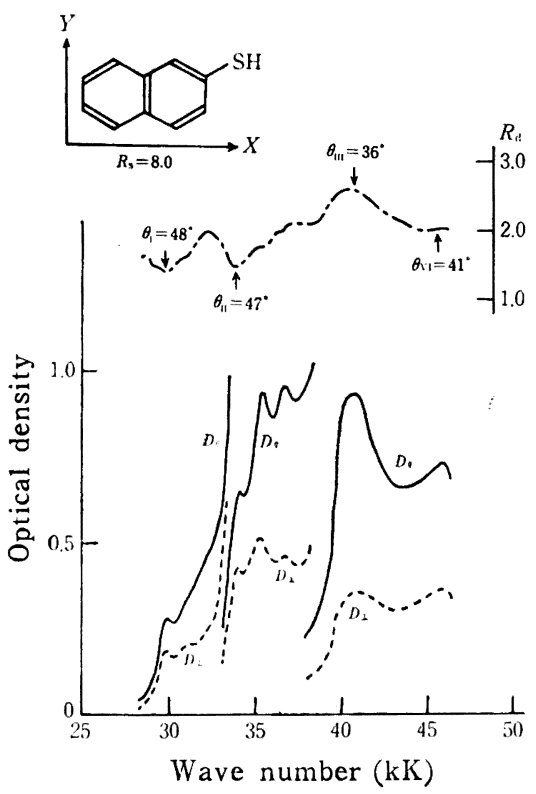

Fig. 1 The polarized absorption spectrum of 2-naphthalenethiol in the stretched polymer film

6) K. Nishimoto, L. S. Forster, J. Phys. Chem., 72, 914 (1968).

7) Y. Tanizaki, S. Kubodera, J. Mol. Spectry., 24, 1(1967).
2 の位置に電子供与性の固換基を導入することにより ${ }^{1} L_{\mathrm{b}}$ 帯の分 極方向が大きく ${ }^{1} L_{\mathrm{a}}$ 帯の分極方向にかたさけられると報告して いる。

図 2 に2-ナフタレンチオールの炭素-硫黄間の共鳴積分 $\left(\beta_{\mathrm{CS}}\right)$ の值を種々に変化させた場合の PPP 計算による各遷移エネルギ 一を示した。この四から明らかなよらに，いずれの共鳴積分の値 を用いても遷移エネルギーに関しては実測値に近い值をとってい る。したがってこのことから最適の $\beta_{\mathrm{CS}}$ の值を見いだすことは不 可能である。そこで本研究では遷移モーメントの実測值と計算值 との比較から最適の $\beta_{\mathrm{CS}}$ を見いたすすととにたた。図 3 に種々の $\beta_{\mathrm{CS}}$ の值を用いた場合の実測値および計算による $33.9 \mathrm{kK}$ 帯の相

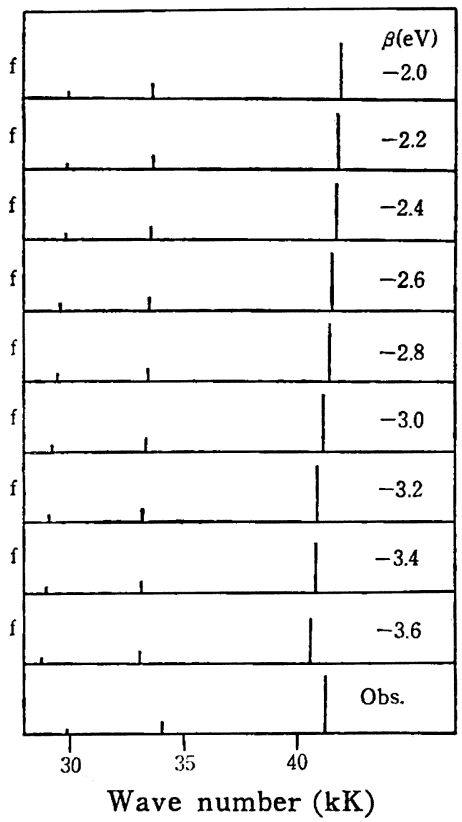

Fig. 2 Changes in the transition energies of 2-naphthalenethiol for the variation of the resonance integrals $\left(\beta_{\mathrm{CS}}\right)$

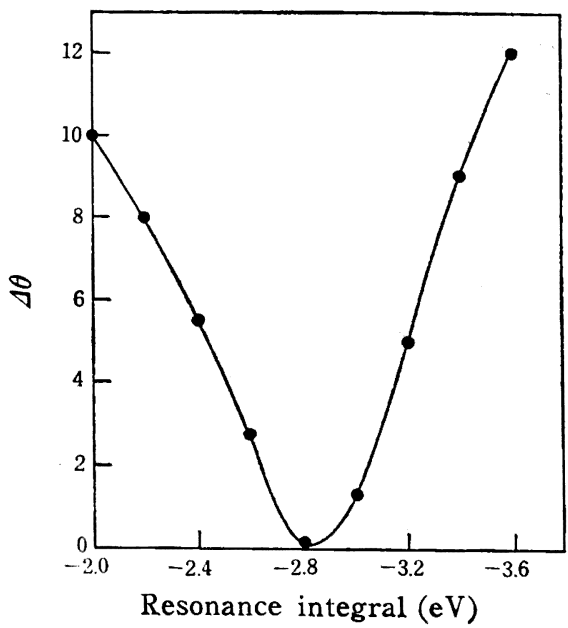

Fig. 3 The variation of $\Delta \theta$ for the second electronic transition of 2-naphthalenethiol with the change in the value of the resonance integral $\left(\beta_{\mathrm{CS}}\right)$

$\Delta \theta:$ Difference between the calculated value of the relative polarization direction, with respect to the polarization of the first transition, and the observed one. 
Table 1 Comparison of the calculated results with observed ones for 2-naphthalenethiol

\begin{tabular}{|c|c|c|c|c|c|c|c|}
\hline & \multicolumn{2}{|c|}{$\begin{array}{c}\text { Transition energy } \\
\text { eV }(\mathrm{kK})\end{array}$} & \multicolumn{2}{|c|}{ Intensity } & \multirow{2}{*}{$\begin{array}{c}\text { Polarization } \\
\text { direction }\left({ }^{\circ}\right) \\
\text { Calc. }{ }^{d)}\end{array}$} & \multicolumn{2}{|c|}{$\begin{array}{c}\text { Relative } \\
\text { polarization }{ }^{e}\left({ }^{\circ}\right)\end{array}$} \\
\hline & Calc. & $\overline{\left.\text { Obs. }^{a}\right)}$ & Calc. ${ }^{b)}$ & Obs. ${ }^{c}$ ) & & Calc. & Obs. \\
\hline I & 3. $66(29.5)$ & 3. $69(29.8)$ & 0.0421 & 852 & -59 & & \\
\hline II & 4. $14(33.4)$ & 4. $20(33.9)$ & 0.1388 & 3215 & -60 & 1 & 1 \\
\hline III & $5.12(41.3)$ & 5. $05(40.7)$ & 1. 6727 & 3458 & 13 & 72 & 84 \\
\hline N & $5.13(41.4)$ & & 0.0311 & & -63 & & \\
\hline $\mathrm{V}$ & 5. $40(43.6)$ & & 0.1488 & & 30 & & \\
\hline M & $5.67(45.7)$ & $5.68(45.8)$ & 0.5801 & 3268 & -57 & 2 & 7 \\
\hline ИI & $5.76(46.4)$ & & 0.0643 & & 69 & & \\
\hline
\end{tabular}

a) In the PVA film. b) Oscillator strength. c) Molar extinction coefficient. d) With respect to the $x$-axis. $e$ ) Relative polarization direction with respect to the first band.

対的分極方向(第 1 吸収帯の分極方向に対する)の差を示した。こ

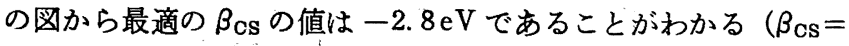
$-2.8 \mathrm{eV}$ のところで最小值を示している)。この $\beta_{\mathrm{CS}}$ の值を用い た場合の計算結果を実測值と比較して示せば表1のようになり， 遷移エネルギー，吸収強度および相対的分極方向のいずれも実測 値とのよい一致を示している。

\subsection{2-ナフタレンチオールの電子带の帰属}

さきに述べたよらに2-ナフタレンチオールの近紫外部の吸収 スペクトルは 29.8，33.9，40.7 㧊よび $45.8 \mathrm{kK}$ の四つの吸収帯 からなっており，これらの吸収帯はそれぞれ表 1 亿示した計算結 果の遷移 I，II，IIIおよびVに対応している。遷移 I，II および IIIに関与する各励起状態の全波動関数は

$$
\left.\begin{array}{l}
\Psi_{\text {I }}=0.543 \chi_{5,7}-0.261 \chi_{5,8}+0.559 \chi_{6,7}+0.535 \chi_{6,8} \\
\Psi_{\text {I }}=0.420 \chi_{5,7}-0.764 \chi_{6,7}+0.434 \chi_{6,8} \\
\Psi_{\text {II }}=0.696 \chi_{6,7}-0.663 \chi_{6,8}
\end{array}\right\}
$$

となる。ここで, $\chi_{i, j}$ は $i$ 番目の被占軌道から $j$ 番目の空軌道へ 1 個の電子が励起した配置の波動関数である。なお(2)式では各 励起状態が $5 \%$ 以下である配置の波動関数は省略した。，各電子遷 移に関与する MO を模式的に図 4 に示した。な拈この図には比較 のため対応するナフタレンの MO も示してある。この図と (2)式 の波動関数から，2-ナフタレンチオールの遷移 I 〜 IIIのナフタレ ขの ${ }^{1} L_{\mathrm{a}},{ }^{1} L_{\mathrm{b}}$ 抢よび ${ }^{1} B_{\mathrm{b}}$ の寄与の割合を見積れば表 2 のように なり，2-ナフタレンチオールの第 1 遷移は ${ }^{1} L_{\mathrm{b}}$ の寄与が $58 \%$ で あり ${ }^{1} L_{\mathrm{a}}$ の寄与が $31 \%$ であり，この遷移はそのほとんどが ${ }^{1} L_{\mathrm{b}}$ の性格をもったものであると解釈できる。同椂に第 2 遷移は ${ }^{1} L_{\mathrm{a}}$ の寄与が $58 \%$ で，この遷移は ${ }^{1} L_{\mathrm{a}}$ に対応させることができる。 また第 3 遷移は ${ }^{1} B_{\mathrm{b}}$ の寄与が $92 \%$ である。

\subsection{1-ナフタレンチオールの電子带の帰属}

図 5 に1-ナフタレンチオールの延伸高分子膜中に扑ける偏光 吸収スペクトルを示す。この化合物は 28.0，33.1，41.6 および $45.0 \mathrm{kK}$ に四つの吸収帯を示寸。これらの吸収帯に対応する配向 角は低波数側からそれぞれ $51^{\circ}, 50^{\circ}, 46^{\circ}$ および $49^{\circ}$ となっている。 これらの実測値を計算值と比較して示せば表 3 のよらである。こ の表から明らかなよらに，ここで選んだ empirical パラメーター を用いた MO 計算の結果は各遷移の分極方向も含めて実測値に非 常によく一致している。たとえば $33.1 ４ 1.6$ および $45.0 \mathrm{kK}$ 帯 の分極方向の相対的角度 $(28.0 \mathrm{kK}$ 帯の分極方向に対する角度) は それぞれ $101^{\circ} ， 5^{\circ}$ おび $3^{\circ}$ となっており，これらに対応する計 算値は $104^{\circ}, 5^{\circ}, 12^{\circ}$ である。各励起状態の波動関数は
Table 2 Contributions of the ${ }^{1} L_{\mathrm{a}},{ }^{1} L_{\mathrm{b}}$ and ${ }^{1} B_{\mathrm{b}}$ transitions to the first, second and third bands of 2-naphthalenethiol (\%)

\begin{tabular}{cccc} 
& I & II & II \\
\hline${ }^{1} L_{\mathrm{a}}$ & 31 & 58 & - \\
${ }^{1} L_{\mathrm{b}}$ & 58 & 36 & - \\
${ }^{1} B_{\mathrm{b}}$ & - & - & 92
\end{tabular}
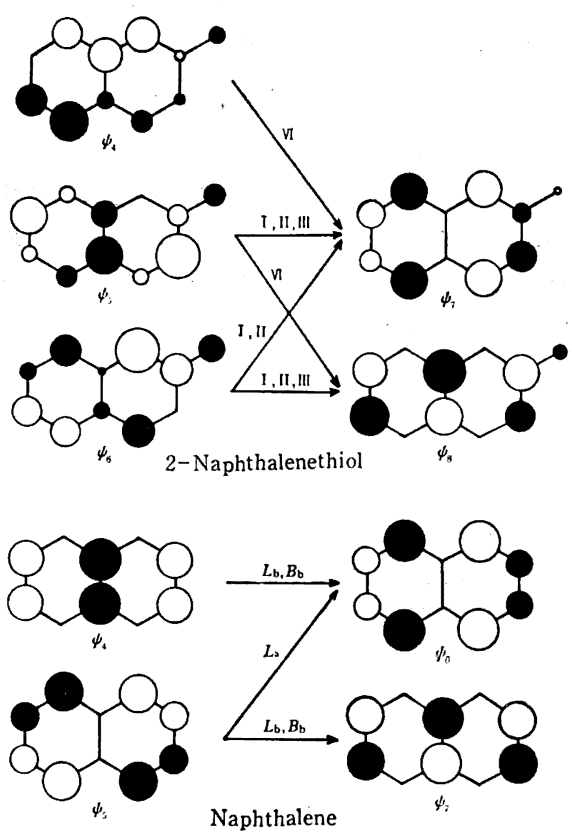

Fig. 4 The diagramatical representations of the $\mathrm{MO}^{\prime} \mathrm{s}$ for 2-naphthalenethiol and naphthalene

The radius of the circle is proportional to the magnitude of the MO coefficients.

$$
\begin{aligned}
\Psi_{\mathrm{I}}= & 0.593 \chi_{5,7}+0.780 \chi_{6,8}+\cdots \cdots \\
\Psi_{\mathrm{II}}= & 0.963 \chi_{6,7}+\cdots \cdots \\
\Psi_{\mathrm{II}}= & 0.221 \chi_{3,7}-0.453 \chi_{4,8}-0.563 \chi_{5,7}-0.362 \chi_{5,9} \\
& +0.454 \chi_{6,8}+\cdots \cdots \\
\Psi_{\mathrm{IV}}= & 0.459 \chi_{4,7}-0.267 \chi_{6,8}-0.826 \chi_{6,9}+\cdots \cdots \\
\Psi_{\mathrm{V}}= & -0.288 \chi_{4,7}+0.381 \chi_{4,8}-0.520 \chi_{5,7}+0.349 \chi_{5,9} \\
& +0.393 \chi_{6,8}-0.326 \chi_{6,9}+0.237 \chi_{6,10}+\cdots \cdots
\end{aligned}
$$

で表わされる。ここで 2-ナフタレンチオールの場合と同様に各 遷移に関与する $\mathrm{MO}$ を模式的に示すと図 6 のよ5になる。この図 と(3)式から，1ーナフタレンチオールの遷移 I ( $28.0 \mathrm{kK}$ 帯) およ 
Table 3 Comparison of the calculated results with observed ones for 1-naphthalenethiol

\begin{tabular}{|c|c|c|c|c|c|c|c|}
\hline & \multicolumn{2}{|c|}{$\begin{array}{c}\text { Transition energy } \\
\mathrm{eV}(\mathrm{kK})\end{array}$} & \multicolumn{2}{|c|}{ Intensity } & \multirow{2}{*}{$\begin{array}{c}\text { Polarization } \\
\text { direction }\left({ }^{\circ}\right) \\
\left.\text { Calc. }{ }^{d}\right)\end{array}$} & \multicolumn{2}{|c|}{$\begin{array}{c}\text { Relative } \\
\text { polarization }^{e}\left({ }^{\circ}\right)\end{array}$} \\
\hline & Calc. & $\overline{\left.\text { Obs. }^{a}\right)}$ & Calc. ${ }^{b)}$ & Obs. ${ }^{c)}$ & & Calc. & Obs. \\
\hline I & $3.72(30.0)$ & $3.47(28.0)$ & 0.0303 & 530 & 7 & & \\
\hline II & 3. $93(31.7)$ & 4. $10(33.1)$ & 0.2448 & 7240 & 83 & 104 & 101 \\
\hline III & $5.04(40.7)$ & $5.16(41.6)$ & 0.6725 & 8100 & 2 & 5 & 5 \\
\hline N & 5. $26(42.5)$ & & 0.0205 & & 77 & & \\
\hline $\mathrm{V}$ & 5. $43(43.8)$ & $5.58(45.0)$ & 0.9031 & 44800 & -5 & .12 & 3 \\
\hline $\mathrm{u}$ & $5.46(44.0)$ & & 0.1136 & & 29 & & \\
\hline
\end{tabular}

a) In the PVA film. b) Oscillator strength. c) Molar extinction coefficient. $d$ ) With respect to the $x$-axis. $e$ ) Relative polarization direction with respect to the first band.

Table 4 The band positions of the ${ }^{1} L_{\mathrm{b}}$ and ${ }^{1} L_{\mathrm{a}}$ transitions of naphthalene and its derivatives in polyvinyl alcohol films

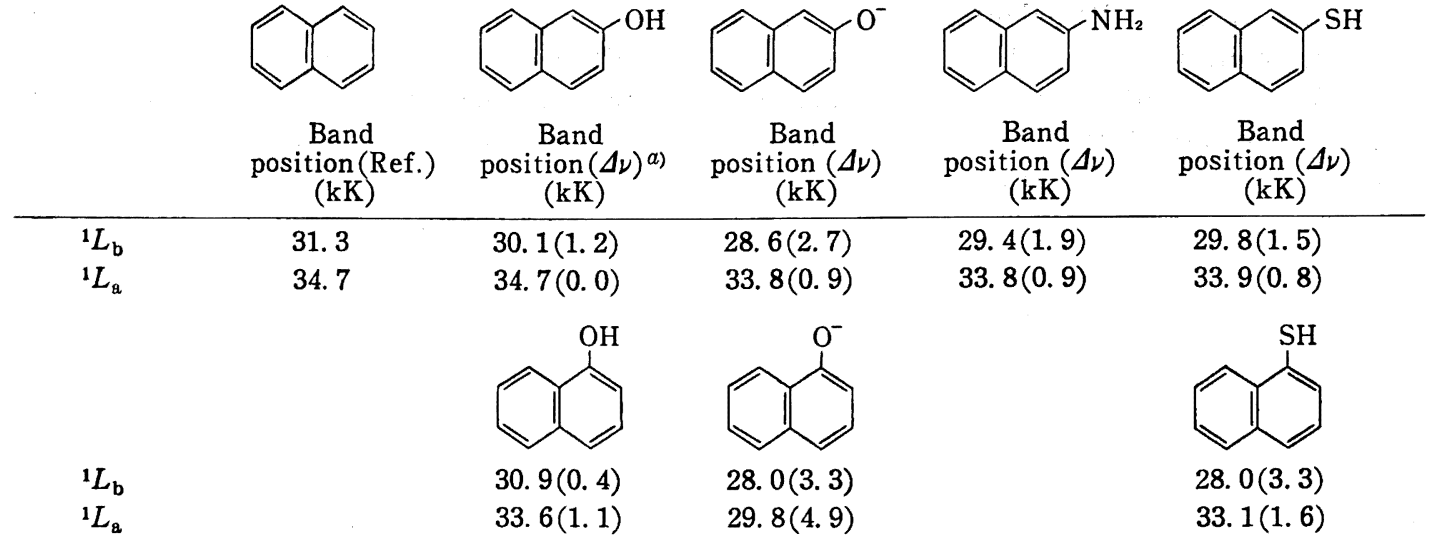

a) $\Delta \nu:$ The difference in wave number from the corresponding band of naphthalene.

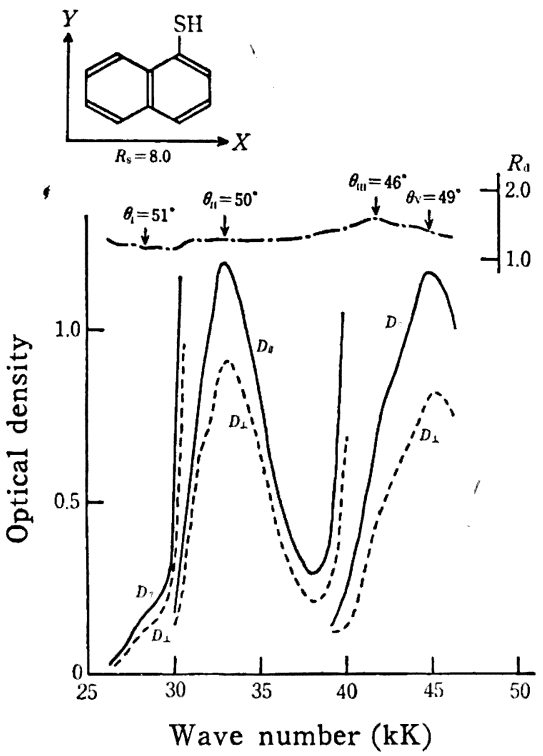

Fig. 5 The polarized absorption spectrum of 1-naphthalenethiol in the stretched polymer film

びII (33.1 kK 帯) はそれぞれナフタレンの ${ }^{1} L_{\mathrm{b}}$ および ${ }^{1} L_{\mathrm{a}}$ に帰属 される。すなわち遷移 I は ${ }^{1} L_{\mathrm{b}}$ の寄与が $96 \%$ であり，遷移 IIは ${ }^{1} L_{\mathrm{a}}$ の寄与が $93 \%$ である。

\section{4 他の置換基の $\pi$-電子系への効果との比較}

水酸基, アミノ基などの $\pi$-電子系への効果については多くの 人々により詳しく研究されている。たとえば谷㥓ら゙はナナタレ

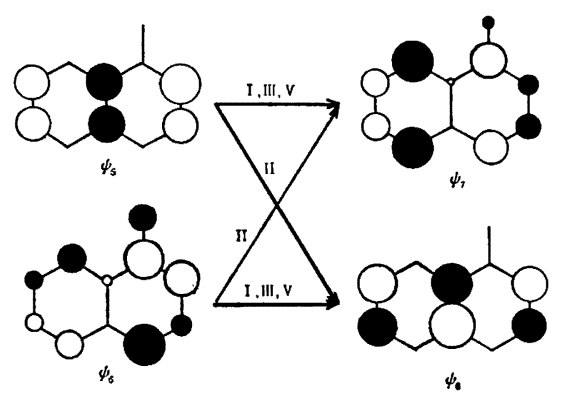

Fig. 6 The diagramatical representations of the MO's for 1-naphthalenethiol

ソスルホン酸の水酸基, アミノ基などの置換体について近紫外部 の吸収スペクトルを測定し，これらの官能基の $\pi$-電子系への効 果について考察している。その結果, 水酸基, アミノ基などの $\pi$-電子系への共鳴効果の大きさは $-\mathrm{NH}_{3}{ }^{+}<-\mathrm{OH}<-\mathrm{NH}_{2}<-\mathrm{O}^{-}$ の順番であると報告している。メルカプト基と 2,3 の官能基の $\pi$-電子系への共鳴効果の大きさ比較する目的で, ナフタレンの ${ }^{1} L_{\mathrm{b}}$ 扎よび ${ }^{1} L_{\mathrm{a}}$ 帯の位置を表 4 に示した。 31.3 および $34.7 \mathrm{kK}$ に あるナフタレンの ${ }^{1} L_{\mathrm{b}}$ および ${ }^{1} L_{\mathrm{a}}$ 帯は置換基の導入によりいずれ も低波数側へ移行している。置換基の導入による両吸収帯のシフ トの度合から官能基の $\pi$-電子系への共鳴効果の大小を推定する とつぎのよらな順番となる。

$$
-\mathrm{OH}<-\mathrm{SH}<-\mathrm{NH}_{2}<-\mathrm{O}^{-}
$$

8) Y. Tanizaki, H. Inoue, N. Ando, Bull. Chem. Soc. Jap., 3̧, 1419 (1965). 


\section{The Resonance Effect of the Mercapto Group on $\pi$-Electronic Systems \\ Junko Yoshino, Hisao Kawai and Toshihiko Hoshi \\ Department of Chemistry, College of Science and Engineering, Aoyama Gakuin University ; Chitosedai, Setagaya-ku, Tokyo 157 Japan}

From the measurements of polarized absorption spectra using stretched polymer films and PPP calculations, we determined the polarization direction of each electronic transition of 1and 2-naphthalenethiol and discussed the influence of the mercapto group on $\pi$-electronic systems. The empirical parameters of the mercapto group required for the PPP calculations were estimated as follows: The second ionization potential of the sulfur atom has been approximated by $I_{\mathrm{P}}\left(\mathrm{S}^{+}\right)=I_{\mathrm{P}}(\mathrm{S})+(\mathrm{SS} \mid \mathrm{SS})=22.3 \mathrm{eV}$, where $I_{\mathrm{P}}(\mathrm{S})$ is the first ionization potential of the sulfur atom. The resonance integral between carbon and sulfur atoms, $\beta_{\mathrm{CS}}$, was assumed from the results of the polarized absorption spectrum; the optimum value of $\beta_{\mathrm{cs}}$ was $-2.8 \mathrm{eV}$. The results of the PPP calculations by use of the empirical parameters obtained here were in good agreement with the observed ones. The magnitude of the resonance effect of the mercapto group on $\pi$-electronic systems was compared with those of the other substituents (amino group etc.). The order of the magnitude of the resonance effect was as follows; $-\mathrm{OH}<-\mathrm{SH}<-\mathrm{NH}_{2}$ $<-\mathrm{O}^{-}$. 